\title{
Association of rs11209032 and rs1004819 Polymorphisms in Interleukin-23 Receptor Gene With Ankylosing Spondylitis
}

\author{
Müjgan ÖZDEMİR ERDOĞAN, ${ }^{1}$ Tuğba Şule ÇANKAYA, ${ }^{1}$ Alper Murat ULAŞLI, ${ }^{2}$ Saliha Handan YILDIZ, \\ Evrim Suna ARIKAN TERZİ, ${ }^{1}$ Tuba ÇAVDAR, ${ }^{2}$ Ümit DÜNDAR, ${ }^{2}$ Mustafa SOLAK ${ }^{1}$ \\ ${ }^{1}$ Department of Medical Genetics, Medical Faculty of Afyon Kocatepe University, Afyonkarahisar, Turkey \\ ${ }^{2}$ Department of Physical Medicine and Rehabilitation, Medical Faculty of Afyon Kocatepe University, Afyonkarahisar, Turkey
}

\begin{abstract}
Objectives: This study aims to investigate the distribution of human leukocyte antigen B27 (HLA-B27) alleles (+/-) and interleukin-23 receptor (IL-23R) gene rs11209032 and rs1004819 polymorphisms among ankylosing spondylitis (AS) patients in a Turkish cohort.

Patients and methods: The study sample comprised 106 AS patients ( 89 males, 18 females; mean age 38.9 \pm 10 years; range 19 to 65 years) and 82 healthy controls (70 males, 12 females; mean age 32.15 \pm 7.07 years; range 19 to 51 years). Distribution of HLA-B27 alleles (+)/(-) in AS patients were observed by reverse hybridization technique. Genotyping of IL-23R rs11209032 and rs1004819 polymorphisms of AS patients and healthy controls were performed by real time polymerase chain reaction.

Results: Of the AS patients, 69 (65.1\%) were HLA-B27 positive. Distribution of rs 11209032 genotype frequencies in AS group were $31.1 \%$ for GG, $50.9 \%$ for GA, and $17.9 \%$ for AA; while in control group, it was $34.1 \%$ for GG, $53.7 \%$ for GA, and $12.2 \%$ for AA. Distribution of rs 1004819 genotype frequencies in AS group were $30.2 \%$ for CC, $52.8 \%$ for CT, and $17.0 \%$ for TT; while in control group, it was $42.7 \%$ for $\mathrm{CC}, 46.3 \%$ for $\mathrm{CT}$, and $11.0 \%$ for TT. There was no significant difference between AS patients and controls in terms of genotype frequencies of IL-23R gene rs11209032 and rs1004819 polymorphisms.
\end{abstract}

Conclusion: No association was found between AS and IL23R rs11209032 and rs1004819 polymorphisms in this Turkish AS cohort.

Keywords: Ankylosing spondylitis; human leukocyte antigen B27; interleukin-23 receptor gene; polymorphism.

Ankylosing spondylitis (AS) is the prototype of a group of inflammatory diseases which share epidemiological, clinical, anatomopathological, radiological, and immunogenetic features. ${ }^{1}$ The age- and sex-adjusted prevalence was estimated to be $0.49 \%$ for $\mathrm{AS}^{2}$ in Turkey, and the prevalence of the disease is between 0.1 and $1.4 \%$ worldwide. $^{3}$ The exact pathogenesis of AS, the common form of spondyloarthritis, remains unknown. Human leucocyte antigen B27 (HLA-B27) has the most important role in etiopathogenesis of AS, and contributes to $20 \%$ to $30 \%$ of the genetic risk. HLA-B27 is positive in $90 \%$ to $95 \%$ of Caucasian AS patients. ${ }^{4,5}$ AS occurs in up to $75 \%$ of monozygotic twins compared to $27 \%$ in
HLA-B27 positive dizygotic twins, indicating that there is a substantial non-major histocompatibility complex (MHC) genetic component underlying the disease. ${ }^{4}$ The interleukin-23 receptor (IL-23R) gene, which is located on chromosome 1p31, is considered to have a role in molecular basis of AS pathogenesis. ${ }^{6}$ IL-23 gene, a member of the hematopoietin receptor family, is formed by two cytokine receptor domains and encodes IL-23R. ${ }^{7}$ IL-23R and its ligand IL-23 are key components of the immunoregulatory pathway. Recent studies have shown that some single nucleotide polymorphisms (SNPs) of the IL-23R gene are strongly associated with several autoimmune diseases, such as Crohn's disease, AS, and Behçet's 
disease. ${ }^{8}$ Because of the similarities between AS and these diseases in clinical and immunological aspects, near-term scientific studies focused on the relationship between gene polymorphisms of IL-23 and AS. Burton et al. ${ }^{9}$ genotyped 14,436 SNP in AS patients and reported presence of an association between IL-23R polymorphisms and AS. Among these SNPs, rs11209032 is localized at intergenic region and does not encode an amino acid. Besides, this SNP is thought to be associated with the shearing of messenger ribonucleic acid or have a function in the interaction of IL-23R and its adjacent gene IL-12RB2 by an unknown mechanism. ${ }^{10}$ Qian et al. ${ }^{11}$ reported that the rs1004819 SNP is localized in intron and may exert its influence by regulating differential splicing of IL-23R messenger ribonucleic acid. Both polymorphisms may affect the splicing process of IL-23R messenger ribonucleic acid which may explain the relationship between these SNPs and AS. To our knowledge, the IL-23R gene polymorphism has not been studied in Turkish AS cohort yet.

In this study, we aimed to investigate the distribution of HLA-B27 alleles (+/-) and IL-23R gene rs11209032 and rs1004819 polymorphisms among AS patients in a Turkish cohort.

\section{PATIENTS AND METHODS}

The study was conducted in Afyon Kocatepe University Faculty of Medicine between January 2013 and January 2014. The study sample comprised 106 AS patients (89 males, 18 females; mean age $38.9 \pm 10$ years; range 19 to 65 years) diagnosed according to 1990 New York criteria and 82 healthy controls (70 males, 12 females; mean age $32.15 \pm 7.07$ years; range 19 to 51 years). Patients were carefully screened, and those with a history of inflammatory disease other than AS and malignity were excluded. All participants provided written informed consent and the study was performed under a protocol approved by the local Medical Ethics Committee. The study was conducted in accordance with the principles of the Declaration of Helsinki. About $2 \mathrm{~mL}$ aliquots of peripheral blood samples were collected from the participants and stored in ethylenediaminetetraacetic acidcoated vacutainers. Genomic deoxyribonucleic acid (DNA) was extracted from a $200 \mu \mathrm{L}$ peripheral blood sample by using a High Pure Template Preparation kit (Roche Diagnostics, Mannheim, Germany). Then, DNA amount and DNA purity were quantified for each DNA sample by Nanodrop ND-1000 spectrophotometer V 3.7 (NanoDrop Technologies Inc., Wilmington, DE, USA). DNA samples were stored at $-20{ }^{\circ} \mathrm{C}$ until they were analyzed. Distribution of HLA-B27 alleles (+/-) in AS patients were performed by reverse hybridization technique using HLA-B27 StripAssay ${ }^{\circledR}$ (ViennaLab Diagnostics $\mathrm{GmbH}$, Vienna, Austria). Genotyping of IL-23R rs11209032 and rs1004819 polymorphisms of AS patients and healthy controls were performed by real time polymerase chain reaction on a LightCycler $^{\circledR} 480$ real-time polymerase chain reaction system (Roche Diagnostics, Vienna, Austria) using LightCycler ${ }^{\circledR}$ FastStart DNA Master HybProbe (Roche Diagnostics, Mannheim, Germany), LightSNIP IL-23R rs11209032 and IL-23R rs1004819 Reagent Mix (Tib Molbiol, Berlin, Germany).

\section{Statistical analysis}

Statistical analysis was performed using the PASW Statistics for Windows, version 18.0 (SPSS Inc., Chicago, IL, USA) software program. In patients and controls, allele and genotypic frequencies related to IL-23R gene rs11209032 and rs1004819 polymorphisms were compared using Chi-square test. Comparison of HLA-B27 allele (+/-) distribution and rs11209032 and rs1004819 frequencies among AS patients with or without a family history of AS was made using chi-square test.

\section{RESULTS}

Sixty-nine AS patients (65.1\%) were found positive and $37(34.9 \%)$ were found negative in terms of HLA-B27 alleles. Distribution of rs11209032 genotype frequencies in AS group were 31.1\% for GG, $50.9 \%$ for GA, and $17.9 \%$ for AA; while in control group, it was $34.1 \%$ for GG, $53.7 \%$ for GA, and $12.2 \%$ for AA. Distribution of rs 1004819 genotype frequencies in AS group were $30.2 \%$ for CC, $52.8 \%$ for CT, and $17.0 \%$ for TT; while in control group, it was $42.7 \%$ for CC, $46.3 \%$ for $\mathrm{CT}$, and $11.0 \%$ for TT. Of the patients with AS, $31.9 \%$ had a family history of AS, while $68.1 \%$ 
had no family history of AS. In patients with a family history of AS, the HLA-B27 positivity increased to 78.3\%; while in AS patients with a negative family history of AS, the frequency of HLA-B27 positivity was $61.2 \%$. However, the difference did not reach a statistically significant value $(\mathrm{p}>0.05)$.

Genotype and allele frequencies of AS patient and control groups in terms of IL-23R gene rs11209032 and rs1004819 polymorphisms are shown in Table 1. There was no significant difference in genotype and allele frequencies of both polymorphisms between AS patient and control groups ( $p>0.05)$. Genotype distribution of rs11209032 and rs1004819 polymorphisms with regards to the family history of AS are shown in Table 2. The differences between AS patients with or without a family history of AS were not statistically significant ( $p>0.05)$. A comparison of the genotype frequencies of rs11209032 and rs1004819 polymorphisms in HLA-B27 positive and negative AS patients revealed no significant difference ( $p>0.05$ ) (Table 3).

\section{DISCUSSION}

The primary goal of the current study was to investigate the association between rs11209032 and rs1004819 polymorphisms in IL-23R gene and AS in Turkish population. Secondly, we assessed HLA-B27 allele frequency in AS patients. The major findings were as follows: (i) No significant association was found between these polymorphisms and AS in this patient cohort. (ii) HLA-B27 allele frequency was low compared to Caucasians. (iii) Distribution of genotype frequencies of rs11209032 and rs1004819 polymorphisms in AS patients were similar between HLA-B27 positive and negative groups. To the best of our knowledge, this study is the first investigating IL-23R gene polymorphisms in Turkish population.

Ankylosing spondylitis, the prototypic seronegative arthropathy, is known to be highly heritable, with $>90 \%$ of the risk of developing the disease determined genetically. ${ }^{12,13}$ Genetic factors have been strongly implicated in its etiology. ${ }^{4}$ Despite the prominence of HLA-B27 in genetic susceptibility of AS, its contribution to overall genetic predisposition is only between $16 \%$ to $40 \%$. Furthermore, since the genetic contribution of the entire $\mathrm{MHC}$ region in AS is at most $50 \%$, genetic factors residing outside the MHC region account for a substantial portion of the overall genetic effect in AS. ${ }^{14,15}$ Timms et al. $^{16}$ demonstrated suggestive linkage of AS

\begin{tabular}{|c|c|c|c|c|c|c|c|}
\hline & \multicolumn{3}{|c|}{ AS group $(n=106)$} & \multicolumn{3}{|c|}{ Control group $(\mathrm{n}=82)$} & \multirow[b]{2}{*}{$p$} \\
\hline & $\mathrm{n}$ & $\%$ & $p$ & $\mathrm{n}$ & $\%$ & $p$ & \\
\hline \multicolumn{8}{|l|}{ rs11209032 } \\
\hline \multicolumn{8}{|l|}{ Genotypes } \\
\hline GG & 33 & 31.1 & & 28 & 34.1 & & 0.555 \\
\hline GA & 54 & 50.9 & & 44 & 53.7 & & \\
\hline AA & 19 & 17.9 & & 10 & 12.2 & & \\
\hline $\mathrm{GA}+\mathrm{AA}$ & 73 & 68.9 & 0.703 & 54 & 65.9 & 0.248 & 0.663 \\
\hline Alleles & 212 & & & 164 & & & \\
\hline $\mathrm{G}$ & 120 & 56.6 & & 100 & 60.98 & & 0.393 \\
\hline A & 92 & 43.4 & & 64 & 39.02 & & \\
\hline \multicolumn{8}{|l|}{ rs1004819 } \\
\hline \multicolumn{8}{|l|}{ Genotypes } \\
\hline CC & 32 & 30.2 & & 35 & 42.7 & & 0.167 \\
\hline $\mathrm{CT}$ & 56 & 52.8 & & 38 & 46.3 & & \\
\hline $\mathrm{TT}$ & 18 & 17.0 & & 9 & 11.0 & & \\
\hline $\mathrm{CT}+\mathrm{TT}$ & 74 & 69.8 & 0.437 & 47 & 57.3 & 0.782 & 0.092 \\
\hline Alleles & 212 & & & 164 & & & \\
\hline C & 120 & 56.6 & & 108 & 65.9 & & 0.068 \\
\hline $\mathrm{T}$ & 92 & 43.4 & & 56 & 34.1 & & \\
\hline
\end{tabular}

AS: Ankylosing spondylitis; Genotypic frequencies of interleukin-23 receptor rs11209032 and rs1004819 polymorphisms between ankylosing spondylitis patients with and without a family history of ankylosing spondylitis. 
Table 2. Genotypic frequencies of interleukin-23 receptor rs11209032 and rs1004819 polymorphisms between ankylosing spondylitis patients with and without a family history of ankylosing spondylitis

\begin{tabular}{|c|c|c|c|c|c|}
\hline & \multicolumn{2}{|c|}{$\begin{array}{l}\text { Family history } \\
\qquad(+)(n=40)\end{array}$} & \multicolumn{2}{|c|}{$\begin{array}{l}\text { Family history } \\
\qquad(-)(n=66)\end{array}$} & \multirow[b]{2}{*}{$p$} \\
\hline & $\mathrm{n}$ & $\%$ & $\mathrm{n}$ & $\%$ & \\
\hline \multicolumn{6}{|c|}{ rs11209032 } \\
\hline \multicolumn{6}{|c|}{ Genotypes } \\
\hline GG & 15 & 37.5 & 21 & 31.8 & \multirow{3}{*}{0.338} \\
\hline GA & 20 & 50.0 & 29 & 43.9 & \\
\hline AA & 5 & 12.5 & 16 & 24.2 & \\
\hline \multicolumn{6}{|c|}{ rs1004819 } \\
\hline \multicolumn{6}{|c|}{ Genotypes } \\
\hline CC & 14 & 35.0 & 22 & 33.3 & \multirow{3}{*}{0.845} \\
\hline $\mathrm{CT}$ & 21 & 52.5 & 33 & 50.0 & \\
\hline TT & 5 & 12.5 & 11 & 16.7 & \\
\hline
\end{tabular}

to chromosome $2 \mathrm{q} 13$, a region containing the IL-1 family gene cluster, and IL-23R gene on chromosome $1 \mathrm{q}$ as strong candidates for involvement in the disease.

Human leucocyte antigen-B27 is a MHC class I molecule that is encoded on chromosome $6 \mathrm{p} .{ }^{17}$ There is a wide range of variation in the frequency of HLA-B27 allele and the distribution of its subtypes across populations which has a significant impact on the prevalence of AS in different racial/ethnic groups. ${ }^{18}$ Roberts et al. ${ }^{19}$ reported that HLA-B27 allele was positive in 164 (93.2\%) of 176 AS patients in a New Zealand population. In two different studies held in Chinese population, $\mathrm{Yi}$ et $\mathrm{al}^{20}$ reported a percentage of $93.3 \%$ of HLA-B27 positivity in 360 AS patients, while Xiong et al. ${ }^{21}$ reported a percentage of $90.7 \%$ in 350 AS patients. On the other hand, in the study conducted in India with a smaller sample size $(n=40)$, Sharma et al. ${ }^{22}$ found a very low frequency of HLA-B27 allele positivity $(30 \%)$ in AS patients. Similar to our findings, the HLA-B27 allele frequency in AS patients were found as 62.5\% in Serbia, 69\% in Qatar, and $71.7 \%$ in Iran populations. ${ }^{\text {[23-25] }}$

The studies carried out in Turkey shows a HLA-B27 allele positivity ranging from 70\% to $74.5 \%$, which is consistent with the findings of the current study. ${ }^{26-28}$ Furthermore, we investigated the frequency of HLA-B27 after dividing AS patients according to presence of family history of AS and detected no significant difference among AS patients with or without a
Table 3. Distribution of genotype frequencies of interleukin-23 receptor rs11209032 and rs1004819 polymorphisms in ankylosing spondylitis patients according to human leukocyte antigen B27 positivity

\begin{tabular}{|c|c|c|c|c|c|}
\hline & \multicolumn{2}{|c|}{$\begin{array}{l}\text { HLA-B27 (+) } \\
\quad(n=67)\end{array}$} & \multicolumn{2}{|c|}{$\begin{array}{c}\text { HLA-B27 (-) } \\
(n=35)\end{array}$} & \multirow[b]{2}{*}{$p$} \\
\hline & $\mathrm{n}$ & $\%$ & $\mathrm{n}$ & $\%$ & \\
\hline \multicolumn{6}{|c|}{ rs11209032 } \\
\hline \multicolumn{6}{|c|}{ Genotypes } \\
\hline GG & 21 & 31.3 & 10 & 28.6 & \multirow{3}{*}{0.945} \\
\hline GA & 34 & 50.7 & 18 & 51.4 & \\
\hline AA & 12 & 17.9 & 7 & 20.0 & \\
\hline \multicolumn{6}{|c|}{ rs1004819 } \\
\hline \multicolumn{6}{|c|}{ Genotypes } \\
\hline $\mathrm{CC}$ & 22 & 32.8 & 10 & 28.6 & \multirow{3}{*}{0.894} \\
\hline $\mathrm{CT}$ & 35 & 52.2 & 19 & 54.3 & \\
\hline TT & 10 & 14.9 & 6 & 17.1 & \\
\hline
\end{tabular}

family history of AS in terms of HLA-B27 allele distribution.

Interleukin-23 plays a key role in both natural and acquired immune system. IL-23 molecule is secreted in peripheral tissues (such as skin, gastrointestinal tract and lung) from activated dendritic cells and macrophages in response to environmental hazardous signals. ${ }^{29,30}$ It is suggested that IL-23 pathway may have important implications in the pathogenesis of chronic inflammatory diseases. ${ }^{10}$ The studies concerning IL-23R gene polymorphisms, conducted on different populations, revealed a strong association with inflammatory bowel disease and psoriasis. ${ }^{31-33}$ In contrast, no association was found between IL-23R gene polymorphisms with rheumatoid arthritis and systemic lupus erythematosus. ${ }^{34,35}$ Because of the similarities between the clinical and immunological aspects of inflammatory bowel disease and AS, scientific studies investigating the impact of genetic factors on AS development focused on the relationship between AS and IL-23R gene polymorphism. ${ }^{10}$ Previous studies have conflicting results since there is no consensus whether IL-23R gene polymorphism has a protective effect against or constitutes a risk factor for AS. ${ }^{9,36-38}$

Dong et al., ${ }^{39}$ studied three SNPs (rs7517847, rs11209032, and rs17375018) in 291 AS patients and 312 healthy controls. Consistent with our findings, they reported no significant difference between two groups in terms of 
genotype and allele frequencies. However, Wang et al. $^{10}$ reported that the differences in the genotypes of rs11209032 and the differences in the genotypes and allele frequencies of rs6677188 between cases and controls were significant. Pimentel-Santos et al. ${ }^{40}$ studied eight SNPs including rs11209032, and they reported no significant association between rs11209032 and AS. However, in the meta-analysis conducted by Karaderi et al. ${ }^{41}$ including a United Kingdom patient cohort, four of the eight SNPs showed significant associations with AS (rs11209032 had the highest association), when cases with inflammatory bowel disease and/or psoriasis were excluded. However, it was stated that these polymorphisms could contribute to either increased or decreased susceptibility to AS. Likewise, in the meta-analysis by Duan et al. ${ }^{42}$ including 11 studies conducted in 13 different populations, it was concluded that the rs11209032 and rs1004819 polymorphisms had associations with increased susceptibility to AS, while rs1343151, rs10489629, and rs11209026 polymorphisms had a protective effect against AS, based on ethnicity. ${ }^{42}$ Furthermore, Lee et al. ${ }^{43}$ reported that although rs 11209032 and rs1004819 polymorphisms have associations with AS in European populations, such associations were not found in Asian populations. Consequently, we were unable to find any association between IL-23R gene rs11209032 and rs1004819 polymorphisms and AS in this study group.

In conclusion, this study revealed no association between rs11209032 and rs1004819 polymorphisms of IL-23R gene and AS in Turkish patients. The previous literature has divergent results in different populations. The reason for the discrepancy may be due to the ethnic differences, regional differences, and limited working group. Beside, AS is a complicated disease and pathogenesis of the disease may vary among patients. However, further studies are necessary to validate or replicate the association between AS and IL-23R polymorphisms in other ethnic population samples.

\section{Declaration of conflicting interests}

The authors declared no conflicts of interest with respect to the authorship and/or publication of this article.

\section{Funding}

The authors received no financial support for the research and/or authorship of this article.

\section{REFERENCES}

1. Gouveia EB, Elmann D, Morales MS. Ankylosing spondylitis and uveitis: overview. Rev Bras Reumatol 2012;52:742-56.

2. Onen F, Akar S, Birlik M, Sari I, Khan MA, Gurler O, et al. Prevalence of ankylosing spondylitis and related spondyloarthritides in an urban area of Izmir, Turkey. J Rheumatol 2008;35:305-9.

3. Braun J, Sieper J. Building consensus on nomenclature and disease classification for ankylosing spondylitis: results and discussion of a questionnaire prepared for the International Workshop on New Treatment Strategies in Ankylosing Spondylitis, Berlin, Germany, 18-19 January 2002. Ann Rheum Dis 2002;61:61-7.

4. Brown M, Wordsworth P. Predisposing factors to spondyloarthropathies. Curr Opin Rheumatol 1997;9:308-14.

5. Maksymowych WP. Spondyloartropathies: Etiology and pathogenesis of ankylosing spondylitis. In: Hochberg M, Silman AJ, Smolen JS, Weinblatt ME, Weisman MH, editors. Rheumatol. 3rd ed. Philadelphia: Elsevier Limited; 2003. p. 1183-92.

6. OMIM (2015). Available from: http://www.omim.org/ entry/607562. [Accessed 6 June 2015]

7. Parham C, Chirica M, Timans J, Vaisberg E, Travis $\mathrm{M}$, Cheung J, et al. A receptor for the heterodimeric cytokine IL-23 is composed of IL-12Rbeta1 and a novel cytokine receptor subunit, IL-23R. J Immunol 2002;168:5699-708.

8. Duerr RH, Taylor KD, Brant SR, Rioux JD, Silverberg MS, Daly MJ, et al. A genome-wide association study identifies IL23R as an inflammatory bowel disease gene. Science 2006;314:1461-3.

9. Burton PR, Clayton DG, Cardon LR, Craddock $\mathrm{N}$, Deloukas P, Duncanson A, et al. Association scan of 14,500 nonsynonymous SNPs in four diseases identifies autoimmunity variants. Nat Genet 2007;39:1329-37.

10. Wang X, Huang J, Lin Z, Liao Z, Li C, Wei Q, et al. Single-nucleotide polymorphisms and expression of IL23R in Chinese ankylosing spondylitis patients. Rheumatol Int 2010;30:955-9.

11. Qian BP, Jiang J, Ji ML, Wang B, Yu Y, Qiu Y. Lack of associations between two previously identified susceptible single nucleotide polymorphisms of interleukin-23 receptor gene and ankylosing spondylitis: a replication study in a Chinese Han population. BMC Musculoskelet Disord 2013;14:190.

12. Rahman P. Genetics of ankylosing spondylitis: an update. Curr Rheumatol Rep 2007;9:383-9. 
13. Brown MA. Breakthroughs in genetic studies of ankylosing spondylitis. Rheumatology (Oxford) 2008;47:132-7.

14. Reveille JD. The genetic basis of ankylosing spondylitis. Curr Opin Rheumatol 2006;18:332-41.

15. Zhang G, Luo J, Bruckel J, Weisman MA, Schumacher $\mathrm{HR}$, Khan MA, et al. Genetic studies in familial ankylosing spondylitis susceptibility. Arthritis Rheum 2004;50:2246-54.

16. Timms AE, Crane AM, Sims AM, Cordell HJ, Bradbury LA, Abbott $\mathrm{A}$, et al. The interleukin 1 gene cluster contains a major susceptibility locus for ankylosing spondylitis. Am J Hum Genet 2004;75:587-95.

17. Zambrano-Zaragoza JF, Agraz-Cibrian JM, GonzálezReyes C, Durán-Avelar Mde J, Vibanco-Pérez N. Ankylosing spondylitis: from cells to genes. Int $\mathrm{J}$ Inflam 2013;2013:501653.

18. Sieper J, Rudwaleit M, Khan MA, Braun J. Concepts and epidemiology of spondyloarthritis. Best Pract Res Clin Rheumatol 2006;20:401-17.

19. Roberts RL, Wallace MC, Jones GT, van Rij AM, Merriman TR, Harrison A, et al. Prevalence of HLAB27 in the New Zealand population: effect of age and ethnicity. Arthritis Res Ther 2013;15:158.

20. Yi L, Wang J, Guo X, Espitia MG, Chen E, Assassi S, et al. Profiling of hla-B alleles for association studies with ankylosing spondylitis in the chinese population. Open Rheumatol J 2013;7:51-4.

21. Xiong J, Chen J, Tu J, Ye W, Zhang Z, Liu Q, et al. Association of HLA-B27 status and gender with sacroiliitis in patients with ankylosing spondylitis. Pak J Med Sci 2014;30:22-7.

22. Sharma N, Sharma V, Masood T, Nautiyal SC, Sailwal, Singh RK, et al. Usage of Conventional PCR Technology for the Detection of HLAB27 Allele: A Significant Molecular Marker of Ankylosing Spondylitis. Indian J Clin Biochem 2013;28:189-92.

23. Vojvodic S, Ademovic-Sazdanic D, Busarcevic 1st. Human leukocyte antigen-b27 and disease susceptibility in vojvodina, serbia. Balkan $\mathrm{J}$ Med Genet 2012;15:55-60.

24. Abdelrahman MH, Mahdy S, Khanjar IA, Siam AM, Malallah HA, Al-Emadi SA, et al. Prevalence of HLAB27 in Patients with Ankylosing Spondylitis in Qatar. Int J Rheumatol 2012;2012:860213.

25. Hajialilo M, Ghorbanihaghjo A, Khabbazi A, Kolahi S, Rashtchizadeh N. Ankylosing spondylitis in iran; late diagnosis and its causes. Iran Red Crescent Med J 2014;16:11798.

26. Gunal EK, Sarvan FO, Kamali S, Gul A, Inanc $\mathrm{M}$, Carin M, et al. Low frequency of HLA-B27 in ankylosing spondylitis patients from Turkey. Joint Bone Spine 2008;75:299-302.

27. İnanır A, Serbülent $Y$, Sarıyıldız MA, Söğüt E. Outcomes of Turkish ankylosing spondylitis patients. Eur J Gen Med 2013;10:145-9.
28. Bodur H, Ataman S, Buğdaycı DS, Rezvani A, Nas K, Uzunca K, et al. Description of the registry of patients with ankylosing spondylitis in Turkey: TRASD-IP. Rheumatol Int 2012;32:169-76.

29. McKenzie BS, Kastelein RA, Cua DJ. Understanding the IL-23-IL-17 immune pathway. Trends Immunol 2006;27:17-23.

30. Lupardus PJ, Garcia KC. The structure of interleukin-23 reveals the molecular basis of p40 subunit sharing with interleukin-12. J Mol Biol 2008;382:931-41.

31. Tremelling M, Cummings F, Fisher SA, Mansfield J, Gwilliam R, Keniry A, et al. IL23R variation determines susceptibility but not disease phenotype in inflammatory bowel disease. Gastroenterology 2007;132:1657-64.

32. Capon F, Di Meglio P, Szaub J, Prescott NJ, Dunster $\mathrm{C}$, Baumber L, et al. Sequence variants in the genes for the interleukin-23 receptor (IL23R) and its ligand (IL12B) confer protection against psoriasis. Hum Genet 2007;122:201-6.

33. Cargill M, Schrodi SJ, Chang M, Garcia VE, Brandon $\mathrm{R}$, Callis KP, et al. A large-scale genetic association study confirms IL12B and leads to the identification of IL23R as psoriasis-risk genes. Am J Hum Genet 2007;80:273-90.

34. Orozco G, Rueda B, Robledo G, García A, Martín J. Investigation of the IL23R gene in a Spanish rheumatoid arthritis cohort. Hum Immunol 2007;68:681-4.

35. Sánchez E, Rueda B, Callejas JL, Sabio JM, OrtegoCenteno N, Jimenez-Alonso $\mathrm{J}$, et al. Analysis of interleukin-23 receptor (IL23R) gene polymorphisms in systemic lupus erythematosus. Tissue Antigens 2007;70:233-7.

36. Rueda B, Orozco G, Raya E, Fernandez-Sueiro JL, Mulero J, Blanco FJ, et al. The IL23R Arg381Gln non-synonymous polymorphism confers susceptibility to ankylosing spondylitis. Ann Rheum Dis 2008;67:1451-4.

37. Davidson SI, Wu X, Liu Y, Wei M, Danoy PA, Thomas G, et al. Association of ERAP1, but not IL23R, with ankylosing spondylitis in a Han Chinese population. Arthritis Rheum 2009;60:3263-8.

38. Sung IH, Kim TH, Bang SY, Kim TJ, Lee B, Peddle L, et al. IL-23R polymorphisms in patients with ankylosing spondylitis in Korea. $\mathrm{J}$ Rheumatol 2009;36:1003-5.

39. Dong $\mathrm{H}$, Li Q, Zhang $\mathrm{Y}$, Tan W, Jiang Z. IL23R gene confers susceptibility to ankylosing spondylitis concomitant with uveitis in a Han Chinese population. PLoS One 2013;8:67505.

40. Pimentel-Santos FM, Ligeiro D, Matos M, Mourão AF, Sousa E, Pinto P, et al. Association of IL23R and ERAP1 genes with ankylosing spondylitis in a Portuguese population. Clin Exp Rheumatol 2009;27:800-6.

41. Karaderi T, Harvey D, Farrar C, Appleton LH, Stone MA, Sturrock RD, et al. Association between the interleukin 23 receptor and ankylosing spondylitis is confirmed by a new UK case-control study and 
meta-analysis of published series. Rheumatology (Oxford) 2009;48:386-9.

42. Duan Z, Pan F, Zeng Z, Zhang T, Wang S, Li G, et al. Interleukin-23 receptor genetic polymorphisms and ankylosing spondylitis susceptibility: a meta-analysis.
Rheumatol Int 2012;32:1209-14.

43. Lee E, Trepicchio WL, Oestreicher JL, Pittman D, Wang F, Chamian F, et al. Increased expression of interleukin 23 p19 and p40 in lesional skin of patients with psoriasis vulgaris. J Exp Med 2004;199:125-30. 